\title{
Early Twentieth-Century Terms for New Verse Forms ('free verse' and others) in Japanese and Arabic
}

\author{
Scott Mehl*
}

\begin{abstract}
In the first half of the twentieth century, when Japanese and Arabic poets began writing free-verse poetry, many terms were proposed as labels for the new form. In addition to the calques on "free verse," neologisms were created to name the new poetry. What is striking is that, in these two quite different literary spheres, a number of the proposed neologisms were the same: for example, in both Japanese and Arabic the terms prose poetry, modern poetry, and colloquial poetry were proposed (among others) as alternatives to the label free poetry. This essay provides an annotated list of the neologisms in Japanese and Arabic, with a list of English terms for comparison; and by referring to the contemporary Japanese and Arabic criticism on the topic of poetic innovation, this essay attempts to explain the similarity between the Japanese and Arabic neologisms. In short, the Japanese and Arabophone arguments in favour of adapting the free-verse form were based on similar premises regarding modernity, freedom, and a vision of literary history that was rooted in an evolutionary theory of genre development.
\end{abstract}

Key words: free verse, modern Japanese poetry, modern Arabic poetry, poetic form

\section{Introduction}

Near the end of his study A History of European Versification, Mikhail Leonovich Gasparov describes free verse - or to use the chronologically earlier term, vers libre $^{1}$ - as a new verse form that has found success in a broad multinational context: "Vers libre is international: it has integrated all the traditions developed by different languages and cultures. Earlier vers libre was perceived against the background of the traditional, more rigorous forms, through its contrast with the latter; now, having become widespread, vers libre itself constitutes a

* Author's address: Scott Mehl, Independent Scholar, 4752 Tatton Park Circle 2B, Winston Salem, NC 27103. E-mail: mehl_scott@hotmail.com.

1 A useful general overview of the history of free verse and vers libre in English is available in Steele 1990: 3-28. On the history of vers libre, vers libres, and vers libérés in French, see Scott 1980: 182-241; Scott 1986: 157-188; Scott 1990: 54-119; Scott 1998: 73-81. 
background against which all other verse forms are perceived" (1996: 286). Gasparov's study treats vers libre as a pan-European phenomenon, but free verse is observable in a far wider geographical area. There are free-verse poems being written in Chinese (Yeh 1991: 22-23; Manfredi 2014: xx-xxi), Japanese, Persian (Karimi-Hakkak 1978: 21-22; Karimi-Hakkak 1995: 247-248), Arabic, and Hebrew (Burnshaw et al. 2003: 355-356), as well. The reasons for this situation are various, but some of them relate to free verse's formal qualities. As T. S. Eliot puts it in a famous formulation in his 1917 essay "Reflections on 'Vers libre," free-verse poetry is characterised by "(1) absence of pattern, (2) absence of rhyme, [and] (3) absence of meter" (Eliot 1975:32) - three absences that it should be possible to replicate in any language. But why would a poet want to replicate those absences? Gasparov would answer that one attraction of the free-verse form is its translatability: "One of the principal reasons why vers libre succeeded was its (relative) ease of translation. Free verse was not linked to national forms of versification and required from its translators only precision of sense and distinctness of style. Therefore it was especially happily accepted by poets in the minor literatures, whose works could find international recognition only in translation" (1996: 284). The prestige of having one's poems translated into other languages is one consideration in favour of a poet's choice to write in a form replicable (in principle) in any language; but it might be added that prestige accrues to the creator of a successful translation of poems, as well, from other languages into her own. ${ }^{2}$

It was precisely the translation of European-language poetry into Japanese and Arabic - to name the two languages under consideration in this essay that catalysed the appearance of free-verse poetry and other new poetic forms. The Japanese and Arabophone critics who set about explicating, debating, advocating, and disparaging the practice of non-traditional poetries in the early twentieth century sought to explain the contemporary literatures of Europe and the Americas even as they sought to come to grips with what was happening in literature in Japanese and in Arabic. There is a distinct comparability between the Japanese and the Arabophone experiences of encounter with European civilisations in the late nineteenth century and the early twentieth century. As the poet and scholar Muhammad Badawi has put it, "there may be some useful parallels to be drawn between the experiences of both

2 Which is not to say that free-verse poetry must be translated into free-verse poetry. Metrically regular poetry is frequently translated into nonmetrical forms; rhymed verse is frequently translated into unrhymed verse. It should be possible to translate free verse into verse-forms that feature patterns of meter or rhyme that would ostensibly make the verse "unfree" in the target language. 
Arabic and Japanese poetry as both were exposed to profound and pervasive Western influences at roughly the same time" (Badawi 1973: 182). By way of suggestion, Badawi adds that this hypothetical parallel between Arabic and Japanese poetries may actually be only one example of a phenomenon observable in "most" of the "world": "there are great stylistic similarities in most of the sophisticated poetry written in the world today, irrespective of the language in which it is composed. [...] [W] e may be moving toward an ideal of poetry which, paradoxical as it may seem, is almost as international as science" (Badawi 1973:182). ${ }^{3}$ I hesitate to endorse Badawi's claim that the free-verse form is an ideal to which all poetry aspires regardless of language; nevertheless, I agree that free verse has made inroads into a multinational and multilingual literary field. As a poetic form, free verse is on its way to becoming an international lingua franca.

While Badawi compares free-verse poetry with science in point of internationality, it seems that free-verse poetry might also be compared with the novel, another literary form that has established a presence in a wide range of languages and literatures. In my understanding of the modern novel's polyglot globality, I follow the comparatist Mary Layoun. In her 1990 study Travels of a Genre: The Modern Novel and Ideology, which centers on novels in Greece, Egypt, and Japan, Layoun claims that "the novel was not and is not a singular, monolithic, and fixed genre but one that emerged in a particular conjunction of sociocultural and literary circumstances and that developed variously in relation to its circumstances" (Layoun 1990: 7). Layoun continues:

[T]he modern West European novel was apprehended and, at least initially, produced in Greece or Egypt or Japan as the paradigmatic genre of the rational, modern, and democratic West, as an 'advanced' cultural technology. Of course, to designate a genre (or a text) as inherently and definitively anything ahistorically ignores the extent to which such designations are themselves historically situated and produced. (9)

In this paper, I beg the reader to make allowances for the differences between the situations of free verse in Japanese and in Arabic. To return to Eliot, if free verse attains its freedom by avoiding some feature of literary language that has traditionally been deemed poetic, then that feature will be tradition-specific:

\footnotetext{
3 Compare Taha Hussayn: "Literature is in need of freedom. [...] Literature should be like all other sciences, subject to research and criticism, analysis, doubt, rejection and denial. The Arabic language should become subject to the work of researchers as matter is to the experiments of scientists" (Aboussena 1986: 208).
} 
a verse that appears free in one language might not appear free in another. Indeed, there can be disagreement over what constitutes a "free" verse even among commentators who share a common language and therefore might be expected to share standards concerning questions of versification. I emphasise that what is referred to as free-verse poetry in Japanese is not the same as its counterpart in Arabic, just as it is not the same as free verse in English or French or any other language.

Instead of attempting a comparison of free-verse poetries in Japanese and Arabic, then, this essay compares the labels, the generic designators that were proposed as names for the new form in both languages: a comparison not of the texts themselves but of the paratexts around them. ${ }^{4}$ These paratexts reveal something - not the whole picture, to be certain, but a crucial part of it - about how the new poetic form free verse was received in two literary traditions in which the prevalent poetic forms were regulated by different prosodic rules. (The point about prosodic rule applies, of course, to the poetries of European languages, too.) When Japanese and Arabophone poets began writing freeverse poetry on European and American models, in both languages a calque was proposed, a phrase that translated "free verse." But at nearly the same time as the calques on "free verse," there also appeared a number of alternative neologisms, new phrases that were proposed as labels for the new poetic forms. What is striking is that in Japanese and in Arabic, many of the neologisms proposed as alternatives to "free verse" were the same. (By "same," I mean only that the terms have approximately the same meaning. Of course the terms were not identical in the two languages.) The Japanese and Arabic cases differ from that of English, in which relatively few terms were proposed; in English, the French term vers libre was and still is used frequently, and the calque free verse established early dominance. In the first part of this essay, I provide an annotated list of the terms that were proposed in Japanese and in Arabic as labels for the new verse forms; in the second part, I contrast the Japanese and Arabic terms with the terms for free verse in English as a way to foreground what the congruence between the Japanese and Arabic terminological spaces

4 Paratexts are the texts that appear around a text: the title, the back cover, the colophon, and so on. My understanding of the paratext is derived from Genette 1987: 7-19. Genette examines generic designations, for example, at Genette 1987: 89-97. However, he concentrates on those generic designations that appear inscribed in or printed on the text itself (e.g., Shakespeare's The Comedy of Errors, Flaubert's Trois Contes). For the purposes of this study, a formal/generic designator that is proposed as a name for a (putatively) new literary form is treated as part of the paratext of any texts written in that form, even if that proposed designation soon falls out of circulation. 
might tell us about the Japanese and Arabic experiences of the "new" or the "modern" in poetry.

A final note about the principle of selection, before delving into the minutiae. The terms that are under examination in this essay were proposed, usually, by a poet or a critic, as designators for the new, nontraditional poetic forms in Japanese and Arabic. Borrowing a term from Saul Kripke, one might think of the proposal of such a generic designator as a kind of baptism (Kripke 1980: 90-97). ${ }^{5}$ In his Naming and Necessity, Kripke explains his baptismal model of naming roughly as follows (I simplify): someone bestows a name upon something, and, if the conditions permit, the initial bestowal sets in motion a causal chain, as the next person repeats the designation, and then a third person repeats the designation, and so on down the line (Kripke 1980: 135-140). The appearance of free-verse poetry in Japanese and Arabic is interesting in part because the new poetic form was baptised with many different names in each language, at different times and by different poets and critics. In some cases, new names were proposed by critics who were unaware of the older names; in other cases, it seems that the critics (or poets) are in competition with one another, vying to be the one who gives the new form a name that becomes common usage. A full-length consideration of these various generic designations would provide a window onto the standards of the literary establishment and onto the relationships among the various poets and critics as they vie for prestige. This essay, be it noted, does not attempt so wide-ranging an investigation. It is simply the beginning piece of such a study, insofar as it assembles the relevant terms for free verse in Japanese and Arabic and offers a commentary on some of the salient similarities between them.

\section{Japanese Terms for New Verse Forms}

In Japan in the first decade of the twentieth century, the most general term for non-traditional poetry written on a largely Western model was shintaishi, meaning "new-style poetry." While the shintaishi is a metrically regular form of poetry, it is an important precursor to Japanese free-verse poetry. In summary, the shintaishi, dating back to the early 1880s, was the creation of three young scholars who had studied in the United States and sought a new Japanese poetic form into which to translate the Anglo-American poetry to which

\footnotetext{
Kripke's original argument is about proper names and the theory of reference; I have adapted his term for the present essay.
} 
they had been exposed. (To my knowledge, no attempt was made to translate Western poetries into haiku or tanka.) The shintaishi could include any number of lines, with variable stanzaic/strophic patterns; in principle it was a flexible form, free to be any length. Each line of a shintaishi was metrically regular, usually based on some combination of 5- or 7-mora clausulae. ${ }^{6}$ Most poems of the seminal 1882 translation anthology Shintaishishō (Collection of New-Style Poetry), for example, were constituted of 12-mora lines in 7-5. Later variants of the shintaishi included recurring lines of 5-7; lines of 5-7-5 alternating with lines of 7-5-7; and others. Metrical and strophic regularity was the rule. The Japanese Symbolist poets of the middle years of the first decade of the twentieth century experimented with alternative shintaishi metrical patterns that included (for example) 4-, 6-, or 8-mora clausulae.

An early mention of the term jiyushi ("free poetry") appears in the introduction to Kaichoon (The Sound of the Tide, 1905), an anthology of translations of European poetries into Japanese shintaishi. The translator of this anthology, Ueda Bin, explains the context in which French vers libre appeared, yet he suggests that Japanese poets would not be amenable to such poetry:

Modern French poetry reached a height in Parnassianism, the resplendent beauty of which was the result of ultimate refining and polishing. But then, at the very apogee of Parnassianism, a 'change of state' was necessitated, and the necessity was realised by Mallarmé and Verlaine. The moment was decisive; they provided the impetus. They began to propagandise for 'Symbolisme'; they encouraged and elucidated the phenomenon of the vers libre form [jiyüshi kei].

The translator of this volume is scarcely the one to say that Japanese poetry should imitate them exactly; my particular bent is more in sympathy with the Parnassians... (adaptation of Kamiyama et al. 1975: 111; Ueda 1905: 240)

Bin's translation of vers libre is jiyushi, "free poetry," a calque of the French term. The term jiyush $i$ was at first not widely circulated. ${ }^{7}$ One factor that limited the use of the term was the absence of free-verse poetry being written

${ }_{6}$ In English-language scholarship, mora is sometimes preferred over syllable to designate the unit of Japanese prosody. I argue elsewhere that the best term is neither mora nor syllable but rather moji, meaning "written character," which is the term that appears in Japanese discussions of Japanese prosody (Mehl 2013: 220-226).

7 Which may explain why some scholars have overlooked Ueda Bin's 1905 use of jiyūshi in their historical treatments of the term. Hitomi Enkichi (Tömei), for example, contends that the earliest use of the term jiyushi is in October 1908: see Hitomi 1954b: 45. Okkotsu Akio later repeats Hitomi's date and cites him as his source (Okkotsu 1991: 3). 
in Japanese; the consensus among Japanese critics is that the first free-verse poems in Japanese were published by Kawaji Ryūkō in the journal Shijin in September $1907 .{ }^{8}$ A little over a year later, in October 1908, the term jiyushi began appearing in writings about poetry; for example, the poet and critic Sōma Gyofū, writing in October 1908, describes the recent debates over "the difference between [...] free poetry [jiyūshi] and prose" (Hitomi 1954b: 45). Henceforth the term jiyushi would become a standard term to refer to nonmetrical poetry in Japanese (Hattori 1963: 161-176). ${ }^{9}$

The term kōgoshi, "colloquial poetry," appeared as early as May 1907 in Hitomi Enkichi's review of a poetry collection by Noguchi Ujō (Hitomi 1954a: 64-66, Hattori 1963: 148-153). At first the term referred to metrically regular poetry written in the so-called colloquial register or kogoo, which was distinguished from bungo, the "literary language"; the term later came to refer primarily to nonmetrical poetry written in the kogo register. To put the matter schematically: with the beginning of the Meiji reign in 1868 and the subsequent program of broad reform, many writers, educators, and politicians held that the difference between spoken Japanese and written Japanese was inconveniently great and might hamper Japanese attempts to adapt the practices of European societies. Hence the so-called genbun itchi movement, the "unification of speech and print," which is typically said to have begun in the 1870's. A new, so-called genbun itchi literary style - marked especially by certain verb endings and adjectival forms that typically had not appeared in literary texts prior to this period - was devised, appearing in literary prose by the mid-1880s (Twine 1991; Tomasi 2004; Jacobowitz 2006). (There is debate over which Japanese fiction was written in the genbun itchi style first, but the usual benchmark is Futabatei Shimei's novel Ukigumo, serialised in 1886-87.) The new genbun itchi style of prose became, within a generation, the default register of literary prose in Japanese. But poetry during the 1880s, 1890s, and the first decade of the 1900s continued to be written in a diction that was marked as archaic-poetic; and with the effects of the genbun itchi movement on contemporary prose, the perceived difference between prose diction and

\footnotetext{
8 The definition of free verse - what a free-verse poem actually is and what distinguishes a free-verse poem from any other kind of poem - is ultimately not at issue in this essay; what is at issue is whether there are readers who agree to call a poem a free-verse poem. On this point see Mehl 2015.

9 By nonmetrical poetry I refer primarily to poetry in which it is not generally possible to explain the disposition of line breaks by referring to the number of syllables or morae or accents in any given line. The poetry that I describe as metrically regular is lineated in accordance with a discernible pattern of syllables/morae/accents.
} 
poetic diction widened. The koggo register was initially identified with contemporary prose, bungo with poetry and the style of pre-Meiji literary texts.

By early 1907, poets began publishing metrically regular shintaishi in a colloquial register with gradually increasing frequency; this poetry was referred to as kogoshi (Hitomi 1954a). ${ }^{10}$ By early 1908 - approximately half a year after the publication of the first nonmetrical poems in a colloquial register - the term koggoshi began to overlap with the term jiyush $i$, insofar as both terms were used to refer to nonmetrical poetry written in a prose-like register.

Other terms related to kōgoshi include koggotai no shi, "poetry of the colloquial style" (by April 1908), its near-equivalent kōgotai shi, "colloquial-style poetry" (also by April 1908), and kögotai no jiyusshi, "free poetry in a colloquial style" (by June 1909) (Okkotsu 1991: 12-15). The latter term is an early version of what is now probably the most common term to refer to modern Japanese poetry in nontraditional forms: kögo jiyusshi.

The term genbun itchi shi, "poetry of genbun itchi," similarly refers originally to metrically regular shintaishi poetry in a colloquial (or genbun itchi) register, from as early as July $1907 .{ }^{11}$ Not long after the publication of the earliest nonmetrical poetry, this term is reconceptualised to refer primarily to nonmetrical poetry - in a colloquial register, as the term suggests.

The term gendaishi, "modern (or contemporary) poetry," was used as early as November 1907; an early instance appears in the critic Shimamura Hōgetsu's article "Gendai no shi" ("Poetry of the Current Age") (Shimamura 1967 [1907]). Shimamura uses the term to describe the poetry of Whitman and Wordsworth and calls for Japanese poets to write similar poetry; he seems not to have known of Kawaji Ryūkō's poems published only two months earlier (and in the same journal, no less). Another term, kindaishi, which also can mean "modern poetry," begins to be used not much later; glimmers of it can be seen in the title of Hattori Yoshika's article "Iwayuru kindaiteki shiika," "The So-Called Modern Poetry" (Hitomi 1967: 898).

The term shizenshugi shi, "Naturalist poetry," refers to nonmetrical poetry in a colloquial register and is used as early as August 1908 (Okkotsu 1967:

10 Other terms for metrically regular, colloquial-register shintaishi include a range of terms that imply a connection with song. The terms zokuyōshi, "popular tune poetry" (as early as September 1908); riyō, "common/popular tunes" (as early as 1908); shinpa zokuyō, "popular tunes of the new school/faction" (as early as 1909); shin zokuyō, "new popular tunes" (as early as 1910); and zokkyoku chō, "the rhythm of popular melody" (as early as 1910) are examined in Okkotsu 1991: 16.

11 Used in an article of the same title by Morikawa Kison, writing under the pen name "Kuzunoha," in the July 1907 issue of the journal Shijin (Okkotsu 1991: 4). 
728; Okkotsu 1991: 6). There was a vogue for what was called Naturalism in contemporary Japanese novels in the first decade of the twentieth century; the term "Naturalist poetry" implicitly compares the poetry so designated with the Naturalist novels, especially in terms of theme. ${ }^{12}$ The journal Waseda bungaku (Waseda Literature, which originated in Waseda University) was most closely associated with the term shizenshugi shi, and when the journal folded the term fell out of use. ${ }^{13}$

The term sanbunshi, "prose poetry," initially refers to nonmetrical poetry in a colloquial register and is used in that sense as early as August $1908 \cdot{ }^{14}$ In its first uses, it is approximately synonymous with the terms jiyushi and koggoshi. As the poet Sōma Gyofū put it in an article published in January 1909, "In the history of poetry in our country there has probably never been so happy a year as 1908. Poetry [now] goes by many names: kōgoshi, or sanbunshi, or jiyūshi..." (Okkotsu 1991: 9-10). Within a few years, however, the term sanbunshi ceases to refer to nonmetrical colloquial-style poetry and is repurposed instead to mean what we generally call "prose poetry" in English or the poème en prose in French: short, unlineated prose pieces. There is also a variant term, kogoteki sanbunshi, "colloquial prose poetry" (Okkotsu 1991: 12).

\section{Arabic Terms for New Verse Forms}

One of the earliest descriptions of European prosody and rhyme in modern Arabic appeared in an 1897 essay by Najib al-Haddād, who uses the term shi'r abyad or "white poetry" as a calque on the English term blank verse. In al-Haddād's description, shi'r abyad refers to unrhymed, metrically regular poetry; the absence of rhyme is treated as a defect, a misfortune brought about

\footnotetext{
12 One of the anonymous readers questioned this description of shizenshugi shi, claiming that the poetry so designated "mostly happened to be nonmetrical and in the colloquial language[;] but poetry of the same sort by non-Naturalists would not be characterised in the same way." That is true. My point is not that shizenshugi shi was the only name for such poetry; I am precisely asserting that it was one of many such designations.

13 Hattori Yoshika also mentions other short-lived terms, such as tanpenshi ("fragment poetry") and inshōshi (“impression poetry”) (Hattori 1963: 105-106).

14 Okkotsu Akio has written that the term sanbunshi appears as early as 1899 but does not give a reference (Okkotsu 1967: 739). As Okkotsu indicates in the same essay (again 1967: 739), the term also appears in Ueda Bin's anthology Miotsukushi (1901), in which there is a selection of Ivan Turgenev's sanbunshi in translation (Bin 1901: 112-131).
} 
by the relative paucity of rhyming words in the European languages. The term shi' r abyad seems not to have entered into general use (van Gelder 1996: 148). ${ }^{15}$

The term shi'r manthūr, "prose poetry," appeared in print as early as $1905 .{ }^{16}$ The Lebanese Jurjī Zaydān, founder and editor of the Cairo periodical Al-Hilāl, used the term to describe a poem published (in the same periodical) by the Ottoman Syrian-born poet Amīn al-Rịhānī. As Rịhānī himself would later explain in a two-paragraph explanation of "Al-shi'r al-manthūr," his poetry was an imitation of Walt Whitman's. ${ }^{17}$ In this brief explanation, Rịhānī explains that the term shi'r manthür renders "Vers Libres" [sic] in French or "Free Verse" in English. He then glosses the term in Arabic as al-shi'r al-hurr al-talìq: "free unrestrained poetry." This form of poetry is distinguished by absence of rhyme (albeit with occasional use of rhyme) and absence of recurring meter (although again it seems that occasionally the presence of a metrical rhythm could be felt). ${ }^{18}$

The adjective manthū $r$ is based on the root $n-t h-r$, meaning "scatter." The word "prose" is nathr, which appears in the term qașidat al-nathr, "qasida in prose," a term coined by the Syrian-Lebanese poet Adūnis as early as 1958 to refer to unrhymed, usually nonmetrical prose-like poetry. ${ }^{19}$

The term shi'r mursal, which also means "prose poetry," appeared in print as early as 1908. (The adjective mursal is based on the root $r$-s-l, meaning "send

15 Al-Ḥaddād's essay is reprinted in Manfalūṭī 1965 [1912]: 120-138 (relevant pages 132-133). Cf. Moreh 1966: 498.

16 I have not been able to inspect the original text in which this term appears. It seems that scholars are divided as to the precise bibliographic reference. Shmuel Moreh gives the following reference: Al-Hiläl, XIII.ii (October 1905), pp. 97-98 (Moreh 1976: 292). Salma Khadra Jayyusi gives the following reference: Al-Hiläl, XIV.ii (November 1905), pp. 97-98 (Jayyusi 1977: 2.631 and 1977: 2.808).

17 Al-Rīhānī renders the name as "Witman" in the original (al-Rịhānī 1910: 2.181; cf. al-Rīhānī 1955: 9). Cf. also Rīhānīs essay "Al-shi'r al-manthūr" (al-Rīhānī 1957: 45-47). Nadeem Naimy suggests that Rịhānìs avoidance of the traditional rhyme and meter might be attributed in part to the fact that Rịhānī had not been schooled in an Arabic-speaking milieu, living as he did in the United States: Rịhānīs "break from the classical seems not to represent a genuine new development, being in reality more of a necessity for him rather than a deliberate artistic choice" (Naimy 1985: 20).

18 On Rịhānī and the shi'r manthūr, sources available in English include Moreh 1968; Moreh 1976: 292-296; Jayyusi 1977: 2.631; Khouri 1987: 103-104; and Imangulieva 2009: 85-121 (where the translator renders shi'r manthūr as "shi'r mansur"). Cf. in Arabic for example Dāwūd 1967: 87-92; 'Izz al-Dīn 2007: 107.

19 An early example of the qașìdat al-nathr is Adūnīs's poem "Waḥdat al-ya’s," which combines short, lineated, occasionally rhymed verse with brief prose paragraphs (Adūnīs 1958). On the qașidat al-nathr see for example Moreh 1976: 305-309; Jayyusi 1977: 2.626-640; Khouri 1987: 109-110. 
forth, unleash.") The Iraqi poet Jamīl Șidqī al-Zahāwī published an unrhymed metrically regular poem, dated 1905, titled "Al-shi'r al-mursal" (Moreh 1966: 490). Moreh describes al-Zahāwī's poem as "us[ing] the tawīl metre, the traditional diction, and the end-stopped line," as well as a "var[iable] type of foot in the darb (the last foot in the line), a technique which is forbidden in Arabic prosody" (Moreh 1966: 491). ${ }^{20}$ The term shi'r mursal is also used by 'Ali Ahmad Bākathīr to refer to the "mixture of blank run-on verse and free verse" he used in translating Romeo and Juliet (Moreh 1966: 496).

The term shi'r hurr, "free poetry," appears as early as 1910 as a calque simultaneously upon two terms, the French vers libres and the English free verse, as explained above in the paragraph on shi'r manthür. In context, then, the term shi' hurr refers originally to unrhymed nonmetrical poetry (albeit with occasional rhymes and with some lines written partially in meter). As the scholar Ahmed al-Tami shows, the term shir hurr would subsequently be used to refer to a variety of other poetic forms, as well. For instance, in 1926 the poet Ahmad Zakī Abū Shādī used the term to refer to unrhymed, polymetric poetry, that is, poetry which "mix[es] different metres in one poem" (al-Tami 1993: 187). ${ }^{21}$ In 1932 the poet Khalil Shaybūb used the term to refer to unrhymed, polypodic, polymetric poetry, seemingly equating the shi'r hurr with the shi'r mutlaq (alTami 1993: 188). In 1943, Duraynī Khashabah defined shi'r hurr as unrhymed, polymetric, monopodic poetry, with the added proviso that shi'r hurr "gives the poet the freedom to create new rhythms" (al-Tami 1993: 188). The Iraqi poet Nāzik al-Malāikah mainly agrees with Khashabah's definition, although Malāikah promotes strict monopody, for example in the introduction to her 1949 poetry collection Shażāya wa-ramād. Malāikah is a major proponent of shi'r hurr as unrhymed, polymetric, monopodic poetry, and her understanding of the term has come to have a wide acceptance; but at the same time, other poets have understood shi'r hurr to mean a kind of unrhymed, polymetric, polypodic verse form (al-Tami 1993: 188-191). By way of summary, it should be noted that the term shi'r hurr has referred to a number of different poetic forms over time, and the meaning of the term is largely context-dependent. Several critics have tried their hands at clarifying the history of the term, and

20 On al-Zahāwī and shír mursal see also Badawi 1975: 50-51; 'Izz al-Dīn 2007: 107.

21 Al-Tami refers to Abū Shādī's poetry collection Al-shafaq al-bākī, in which the term shi'r hurr is followed by the English-language term "Free Verse" in parentheses. (In the same brief prose interpolation, shi'r mursal is followed by the term "Blank Verse" in parentheses.) Abū Shādī 1926: 535. 
while there is some agreement as to dates and persons, there is little agreement on why the term has evolved as it has. ${ }^{22}$

Proposed by the writer Mikhail Naimy in his essay collection Al-ghirbāl (1923), the term shi' $r$ mutlaq (unconstrained poetry) refers originally to unrhymed monometric monopodic poetry (Moreh 1966: 498). The poet Khalil Shaybūb would later use the term shi' $r$ muțlaq to refer to his unrhymed polymetric polypodic poetry, which "employ[ed] more than one metre in each poem, abandon[ed] the two symmetrically formed hemistichs, the monorhyme of the poem, and var[ied] the length of each line according to the exact form of the metre being used" (al-Tami 1993: 188). As noted above, Shaybūb uses the term shi'r mutlaq as a synonym of shir hurr.

The adjective mutlaq derives from the root $t-l-q$, which means "release, unbind, set free." Critics often described the new form of poetry as having been set free from the "strictures" or "bonds" (quyūd) of the old poetry; in such descriptions the word for "set free" is typically derived from the root $t-l-q$. For instance, Niqūlā Fayyāḍ labels an unrhymed, polymetric, monopodic poem he publishes in 1924 as a shi'r țalq (Moreh 1988 [1977]: 430-431). Fayyāḍ also uses the term shi'r taliq (Moreh 1976: 211). Another related term is shir muntaliq, used as early as 1937 to designate unrhymed polymetric monopodic verse. ${ }^{23}$

In 1957 the poet Yūsuf al-Khāl proposed the term shi'r hadith, "modern poetry," as a designator for the new non-traditional poetries (al-Tami 1993: 191). (The term had appeared in print as early as 1953.) ${ }^{24}$ According to Ahmed al-Tami, al-Khāl proposed the term shi' $r$ hadith as an improvement over shi ${ }^{i}$ hurr. al-Tami summarises what he perceives to be the disadvantages of the term shi'r hurr as follows:

The word hurr has, then, generated a kind of contempt for any metrical or rhymed poetry; $[\ldots]$ the word has implied that traditional poetry is 'enslaved.'

\footnotetext{
22 See Moreh 1966: 503-504; Badawi 1975: 225-226; Moreh 1976: 190-212; and Jayyusi 1977: 1.89-91 for an attempt to clarify the various meanings of shi'r hurr, shi'r mursal, and qașidat al-nathr; see also Jayyusi 1977: 2.630, Khouri 1987: 101-105, and al-Tami 1993. In Arabic cf. also al-Yāfī 1986: 103-150; 'Izz al-Dīn 2007: 107-112.

23 'Alī Aḥmad Bākathīr described his 1937 translation of Romeo and Juliet as shi'r muntaliq. Muhammad al-Nuwayhi proposed the same term as a designator for the nontraditional poetry being written with increasing frequency during the postwar years: "an-Nuwayhī [...] explains that the word muntaliq means the freedom to vary the number of feet in each line rather than being restricted by traditional prosody, although this freedom does not extend as far as relinquishing all meter" (al-Tami 1993: 195).

24 Al-Tami claims that "modernity" was being used, by the writer Nihād al-Takarlī, "not only in its historic sense but also its artistic and philosophical sense" (1993: 191).
} 
This arises from an inaccurate application of non-Arabic poetic terms, and some critics believe that the term 'free verse' has been imposed on Arabic poetry. To resolve this problem, poets and critics have introduced, individually, a number of alternative terms. [...] We are seeking a term which distinguishes the poetry based on the irregular recurrence of a traditional taf'ilah [metrical foot] [...] (al-Tami 1993: 191).

As a point of clarification, shi'r hadith, like the term shi'r hurr in one of its 1950s meanings, refers to unrhymed, polymetric, monopodic verse.

The adjective hadith is derived from the root $h$ - $d$-th, which can mean "new, modern." The same root yields several other terms for the new poetries: shi' $r$ al-hadāthah ("poetry of modernity") (al-Tami 1993: 194), al-shi'r al-muhdath ("modern or recent poetry"), ${ }^{25}$ al-shi'r al-mustahdath ("modern or new poetry"). ${ }^{26}$

Similar to the terms invoking modernity is the term shi'r jadid, "new poetry," proposed in 1961 by the Egyptian intellectual Zakī Najīb Mahmūd (al-Tami 1993: 193). Shi'r jadid was meant to be an improvement on the term shi'r hurr. So was the term shi'r mu'ạșir, "contemporary poetry," a commonly used label that may ambiguously refer to the new forms of poetry (roughly equivalent, then, with shi'r hurr), or to any poetry, regardless of form, written in the twentieth century (al-Tami 1993: 194).

The term shi'r al-taf'îlah ("poetry of the taf 'ilah [metrical foot]") was proposed by 'Izz al-Din al-Amin in 1964 as a way to emphasise the monopody of the unrhymed and polymetrical verse being written with increasing frequency in the postwar years (al-Tami 1993: 195). Although the number of feet per line may vary in the new form of poetry (polymetry), and although rhyme is optional, the poetry called shi'r al-taf'ilah hews to one of the sixteen traditional taf'i $i$ at throughout the poem. ${ }^{27}$

\footnotetext{
25 Proposed by Yūsuf al-Khāl in 1978, twenty-one years after he had proposed the term al-shi' $r$ al-hadìth (al-Tami 1993: 197).

26 Used by Ibrāhim al-Ibyārī in 1963 (al-Tami 1993: 197).

27 Al-Tami praises the term shi'r al-taf'illah as the least ambiguous of the labels for the new poetry: it "distinguishes the movement's poetry from other forms, whether new or traditional. As already mentioned, the prosody of [this] poetry [...] is based on using the taf 'ilah freely in each line. This is the main characteristic of this poetry; that is to say, its stylistic structure is based on the taf'ilah. [...] Furthermore, this term can not [sic] apply to any other form of poetry. Thus, it achieves what all the other terms have failed to do. Another advantage is that, unlike ash-shi'r al-hurr, it is not a translated term that is liable to be confused with its meaning in its language of origin" (al-Tami 1993: 198).
} 
The term shi'r al-âmmiyya, "poetry in the colloquial," refers to poetry written "in the Egyptian spoken rather than the standard written register of Arabic" (Radwan 2012: 37). The term was coined in 1961 by a group of Egyptian poets who had written poetry in a diction that drew from the local spoken dialect, rather than from the established canon of poetry alone. "Not all 'ammiyya poetry is written in free verse," the scholar Noha Radwan writes, suggesting that much of it is written in nontraditional prosodic forms (2012: 51). The distinguishing characteristic of shi'r al-ämmiyya is its use of vocabulary that has not hitherto been present in the canonical poetic register - i.e., vernacular or colloquial diction. Rhyme may be present or absent in shi'r al-àmmiyya; likewise with recurrent patterns of meter, line length, or strophic contour.

\section{Conclusions}

While it may not be surprising that in both Japanese and Arabic there are calques for the term "free verse" (jiyushi and shi'r hurr; cf. shi' r țalq and other terms in root $t-l-q$ ), what is striking is, first, that in both languages a number of neologisms were proposed as alternative terms. (There is no reason to assume that a new poetic form will be greeted with many different names. The situation is different in English, as will appear below.) Second, in both languages a calque on "free verse" appeared relatively early in the history of the new form's reception, and in neither language, apparently, did the calque establish such dominance that it prevented the formation of competing neologisms. In schematic form, the following similarities are most noteworthy:

prose poem:

Japanese: sanbunshi

Arabic: $\quad$ shi'r mursal, shi'r manthür, qașidat al-nathr

modern poem:

Japanese: gendaishi, kindaishi

Arabic: $\quad$ shi' $r$ hadith, other terms in root $h$-d-th

colloquial poem:

Japanese: kögoshi, genbun itchi shi

Arabic: shi'ral-âmmiyya 
Why would similar terms be proposed in such different literary contexts? Some of the evidence is to be found in the critics' and poets' writings about the new poetic forms.

Poets and critics gave various reasons both for and against writing the new non-traditional free-verse poetry, but it is possible to tease out a few important themes that are common to the Japanese and Arabic cases. ${ }^{28}$ For one, the new poetic forms were often described as being better adapted to, or more fit for, or better suited to, societies that were undergoing pervasive transformation, and it is not hard to surmise - although it is difficult to prove conclusively - that a vocabulary derived from Darwinian evolutionary theory lay behind such descriptions. ${ }^{29}$ "There can be no doubt whatsoever," Sōma Gyofū comments in an article published in February 1908, "that the complex weave of feelings felt by people today [gendaijin] must suffer severely from the restrictions imposed by historically determined [poetic] forms" (Sōma 1967 [1908]: 336). "Unless poetry breaks its harmful habits, it will not be able to make contact with the hearts of people today [gendaijin]," Gyofū later claims in the same essay (Sōma 1967 [1908]: 337). The poet Miki Rofū places a similar emphasis on the necessity of what might be called relevance to present concerns when he writes, "It is evident that an elegant poetic diction, being at a distant remove from life as it is actually lived [jissai seikatsu], cannot express the thoughts and feelings of the present age" (Miki 1967 [1908]: 355). ${ }^{30} \mathrm{New}$ forms of modern Arabic poetry have been described in similar terms. Shmuel Moreh writes: "shi'r manthūr [prose poetry] was an artistic necessity for a new spiritual and emotional sensibility among young writers who were unable to master Arabic metrics and the diction of conventional Arabic poetry, or felt that the form of the Arabic qașìda was not suitable for their new themes and

\footnotetext{
28 A different approach would have been to place more emphasis on the differences between the Japanese and Arabic terms - for example, attending to the fact that in Japanese there was the term "Naturalist poetry" but not in Arabic, or the fact that in Arabic there was the term "poetry of the [metrical foot]" but not in Japanese, and so on. I believe such a course has merit, but for reasons of space I have decided to concentrate on the similarities between the two traditions.

29 Social Darwinism had a great impact on Japanese thought in the late nineteenth century, by way of translation and by inclusion in university syllabi (Thomas 2001: 103-108); a complete translation of Darwin's Origin of Species had appeared in Arabic by 1928, with partial translations before then (Elshakry 2013: 261-305).

30 Compare Chuzan Senshi's preface to the Shintaishishö: "the ideas which we can exhaustive[ly] convey through such modes of expression as the thirty-one syllables, or satirical verse, are those of a duration no longer than fireworks or shooting stars. When we get ideas in our head with the slightest continuity and try to enunciate them, such modes of expression are basically inadequate" (Kamiyama et al. 1975: 23).
} 
diction" (Moreh 1974: 233). Experiments in shi'r mursal were motivated by a wish to "inject [Arabic poetry] with new blood so as to cope with the development of European literature" (Moreh 1988 [1977]: 427).

The claim that new verse forms were better suited to the contemporary environment was rooted in an attitude toward the past that can best be described as ambivalent. On the one hand, the language in which traditional poetry is written comes to be defined as the non-modern, the not-new: this view is crystallised in the critic Oritake Ryōhōs pronouncement, "The language of the past is a foreign language" (Oritake 1967 [1908]: 351). Similar views can be found in the writings of poets who played a role in promoting non-traditional poetic forms in Arabic. The poet Amīn al-Rịhānī characterises his poetic practice in the following terms, comparing his poetic innovations with resistance to ankylotic manifestations of authority:

[M]y aim throughout has been twofold, namely: to expose and combat the evils of the autocracy and hierarchy under which my country is tottering and to establish a new school of literature in Arabic. [...] Contemporary Arabic literature is still swathed with classic formulas, and I find myself bound to break with the past even in this. The grammarians are just as bad as the priests and the autocracy in point of authority. I am also introducing a sort of free verse into my language [...] such is my work in Arabic. (Naimy 1985: 17-18)

In contrast, some poets and critics who supported the new poetic forms attempted to establish a link between the new and the old. As one of the compilers of the Shintaishisho explains it in his preface:

In Western lands people usually compose poetry using the ordinary vocabulary of the people, and everyone directly expresses what is on his mind. In ancient times we did the same thing in Japan, but when today's scholars compose poetry (shi) they use Chinese words; and when they write Japanese verse (uta) they choose an archaic vocabulary. Ordinary language, treated as inferior and vulgar, is not employed. This cannot but be an error in judgment. (Kamiyama et al. 1975: 19)

Again, a similar type of claim can be found in the writings of Arabophone critics and poets:

in seeking justification for emancipating their verse from [...] rigid quantitative patterns, this group of poets [i.e., who write prose poems] insists on reminding their critics of the often forgotten fact that their freedom is in effect a return to 
the freedom of composition which, three centuries before [the $8^{\text {th }}$ century CE grammarian] al-Khalil formulated his metrics, stimulated the poetic creativity of several generations of pre- and early Islamic poets and gave rise to the rich and varied rhythms of their poetic productions. (Khouri 1987: 112)

While some poets and critics tried to characterise the new verse forms as a salutary break with the stagnant, maladapted forms of the past, other poets and critics asserted that the new forms were actually a recursion to old poetic ideals.

The above considerations help to explain why Japanese and Arabic poets might see fit to refer to the new free-verse poetry as "modern poetry." It is a little harder to explain how the term "colloquial poetry" came to be used in both languages, even granting that the referent of "colloquial" is not precisely the same. In the Japanese case, one of the immediate reasons for promoting a colloquial style in poetry was that the colloquial had made such headway in contemporary prose. The perceived success of the genbun itchi style novel encouraged poets to imitate that success, and the free-verse form was presented as the form of the future - i.e., the form of the present, the form of modernity. If the colloquial register enjoyed such popularity in prose, the poets reasoned, it was because the colloquial register was better suited for addressing the problems of contemporary, real life. In an essay titled "Gendai no shi" ("Modern Poetry"), the critic Shimamura Hōgetsu concludes, "If we think historically, twenty years ago, in Japanese prose, no one would have dreamed of deeming the endings de aru and arimasu suitable for literature [bunshō], but in prose [being written] now, genbun itchi has won. And so shall it be in poetry" (Shimamura 1967 [1907]: 332). The Japanese Symbolist poet Kanbara Ariake likewise compares the colloquial register with contemporary prose: "By genbun itchi, I do not mean the style of popular songs [zokuyōchō, min'yōchō] but rather the language found in contemporary fiction [ima no shōsetsu], the everyday language [futsū no kotoba]..." (Kanbara 1967 [1908]: 333).

In modern Arabic, however, it appears that the colloquial language retains a nonliterary stigma both in prose and in poetry. Writing of the modern Arabic drama and the novel, the scholar Pierre Cachia has stated that " $\mathrm{t}]$ he most important development concerning the colloquial in modern times is that it has gained a foothold in the theatre" - a form that is at least nominally intended for a viva voce presentation - "and [only] a toe-hold in the dialogue of the novel and short story" (Cachia 1990: 66). In their studies published in the last quarter of the twentieth century, the scholars Salma Khadra Jayyusi and Shmuel Moreh both indicate that the use of the colloquial in poetry remains rare: Jayyusi grudgingly admits that " $\mathrm{t}$ ] he sporadic use of colloquial words [...] is perhaps more easily achieved in a prose medium" (1977: 637; cf. 
658-675), while Moreh concludes his study of modern Arabic poetry by saying that "a growing number of poets and critics agree [...] that colloquial poetry is part of the modern Arabic literary heritage and should not be cast out as an inferior genre which has no right to exist," leaving it implicit that the opposition to the colloquial in poetry has been vehement (1976: 318). One of the pioneers of modern colloquial poetry in Arabic intended to create "a popular genre" of poetry, in Noha Radwan's words, "inspired first and foremost by the need for mass communication, and mass education" (2012: 42).

As for the term "prose poetry," a case-by-case analysis is probably the soundest way of proceeding. In the Japanese case, "prose poetry" (sanbunshi) a synonym, temporarily, for the terms "free poetry" (jiyushi) and "colloquial poetry" (koggoshi) - probably referred to the alleged resemblance between the diction of the new poetry and that of contemporary prose (cf. the discussion of the term "colloquial poetry" above). In Arabic, though, there was a "centuries-old [...] tradition of restricting the term shi'r to poetry written in the canonical literary language" (Radwan 2012: 37), and any poetry that did not fit the prescribed scheme of rhythm or rhyme was already partly on its way to being prose. Another point worth mentioning, however, in connection with the term "prose poetry" is the prominence of the novel in both modern Japanese and in modern Arabic. The novel, as has already been suggested in the introduction of this essay, has enjoyed a remarkable international success. One might hypothesise that the novel, even early in the twentieth century, was establishing itself as what the Polish critic Ireneusz Opacki would call a royal genre, a genre whose dominance affects all other literary forms in its environment. According to Opacki, a royal genre "draws toward itself all the remaining literary genres of a given period" (Opacki 2000: 122). "But," Opacki continues, "this does not lead to the fusion of all literature into one genre. The distinguishing features of the various genres survive" (2000: 122). With prose being the medium of the royal genre (i.e., the novel) in both modern Japanese and in modern Arabic, the advocates of a new kind of poetry might positively wish to proclaim it as having the qualities of prose. ${ }^{31}$ These reflections must remain at the level of speculation, however.

It also should be stated that without investigation into other languages and literary traditions, it remains difficult to gauge how noteworthy the similarities

\footnotetext{
31 One might suppose that only the advocates of a free-verse poetry would want to assert its similarity to the (putatively dominant) novel by calling it prose poetry, but it is easy to see that opponents of the free-verse poetry might also see the aptness of such a designation: because they might be likely to argue that free-verse poetry is not poetry at all, but prose.
} 
between the Japanese and Arabic terminologies for free verse really are. ${ }^{32} \mathrm{~A}$ multi-language, multi-tradition study is beyond the scope of this essay, but I will mention that, in comparison with the Japanese and Arabic cases, the English-language terminology for free verse presents a different prospect. The English-language field is dominated by two terms: vers libre, a direct borrowing from French; and free verse, the English calque on the French term. In reference to new forms of poetry being written in English in the first decade of the twentieth century, Annie Finch has written that "it is [...] no accident that the first term used for the new [poetry] movement in English was the French phrase vers libre" (2000: 86). The term appears in English as early as the mid-1880s, with initial reference, as might be expected, to poetry in French. ${ }^{33}$ The term free verse appears as a calque on different but related French terms: vers libres and vers libre. ${ }^{34}$ (The earlier vers libres allowed variable feet and rhyme schemes; vers libre typically referred to unrhymed, unmetrical verse.) For an early use of free verse in a meaning that approximates that of vers libre, one can look to Vance Thompson, whose French Portraits includes the following encomium of free verse: "What is called free verse is merely verse that obeys a larger law than that of uniform syllables and ordered rhyme. The great, brawling strophes of Whitman are based upon a well-reasoned law of verse. And just as Poe created modern French prose, Whitman re-created modern French verse" (Thompson 1900: 70). It is true that individual poets proposed other terms for their own free-verse poetries, but these terms did not have a wide circulation. ${ }^{35}$

32 I thank one of the anonymous readers for this point. The earlier versions of this essay treated the Japanese and Arabic cases only; the anonymous reader recommended that I situate these two terminological fields in relation to a third.

33 "...vers libre, in which the ordinary reader sees nothing but a succession of unequal verses put together without rule at the caprice of the poet" (Tilly 1886: 260). This is Tilley's translation of a passage from the French; he leaves vers libre untranslated.

34 For an example of free verse calqued on vers libres, see Warren 1890.

35 The English writer Martin Tupper described the texts in his 1837 Proverbial Philosophy as "Rhythmics." These were unrhymed short texts without a discernible regular prosody (Hudson 1949: 42-43).

The American poet Amy Lowell referred to some of her poems as unrhymed cadence (1921 [1914]: x). She preferred the term "unrhymed cadence" to the term vers libre primarily because the English term was, she supposed, clearer to English-speaking readers (1921 [1914]: $\mathrm{x})$. Stanley K. Coffman has said that the term "unrhymed cadence" was coined by F. S. Flint (1951: 98-99). (Coffman adds that Flint's unrhymed cadence "is not precisely the concept of the French vers libristes" [1951: 111].) The attribution of the term "unrhymed cadence" seems a contested point: as René Taupin has written, "If Amy Lowell deserves credit for pursuing scientific studies of rhythm the furthest, she was not responsible for originating the theory of 
The term "New Poetry" was "[t]he contemporary name [in English] generally used for Modern verse," according to Chris Beyers (2001: 61). The term had its greatest visibility in connection with the anthologies titled The New Poetry, edited by Harriet Monroe, with the first version appearing in 1917 (Abbott 1984: 90). Walt Whitman also uses the term "new poetry" as the heading of a subsection in his short essay "Ventures on an Old Theme," but it appears he is using the term in a general way (Whitman 1902 [1882]: 271). For the purposes of this essay, the term new poetry catches the eye because of its resonance with the Arabic shi'r jadid (new poetry) and with the Japanese shintaishi (new-style poetry), even though the latter referred to metrically regular poetry. I grant that it is not particularly surprising that a non-traditional variety of poetry would be called new poetry, but it is instructive to note how different were the circumstances in which these terms appeared, and the poetic forms to which they were applied. The Japanese term was coined in 1882 to apply to metrically regular poetry in lyrics of an indeterminate number of lines; the English term was used as early as 1917 to apply, in the main, to what was otherwise called free verse; the Arabic term was proposed as an improvement on the more common shir hurr as late as 1961 (even though the phrase shi' jadid had almost certainly been used earlier than that, albeit without the intention to baptise a poetic form, in the Kripkean sense mentioned in the introduction to this essay).

One point where the English case evidently differs from the Japanese and Arabic is that the terminology for free verse in English has not been perceived as a problem for critical scrutiny. The welter of terms in Japanese and Arabic has occasioned the work of scholarly sifting and reflection; the English terms, it would appear, have not. ${ }^{36}$

A minimal explanation of the similar clusters of Japanese and Arabic neologisms for "free verse" would amount to a history of several concepts in radically different contexts. It would entail a rendering of the ecologies of the concepts of prose, the colloquial, and the modern, to say nothing of the concepts of poetry and freedom, both in Japan and in the Arab world. At the

unrhymed cadence, or 'free verse.' The whole Imagist group, and especially [F. S.] Flint, were responsible for its origin" (1985: 109).

In the Preface to her 1918 collection Can Grande's Castle, Lowell dubbed the four long writings collected therein "polyphonic prose" (Lowell 1918: x). But, aside from a number of lineated passages in the title "poem," the texts in this collection are typeset as prose without line breaks.

36 Steele offers a provocative reflection on the meaning of the fact that the English calque came to be "free verse" instead of "free poetry" (Steele 1990: 285). 
time when free verse poetry was first being written and debated, Japanese and Arabophone critics were actively engaged with many of the literatures of Europe, and therefore it would be necessary to describe and historicise the ecologies of the same concepts in (to set a pragmatic limit) French and English, as well. There is no space here for undertaking so comprehensive a study; for the moment, let this essay stand as a preliminary to future work in comparative poetics. ${ }^{37}$

\section{References}

Abbott, Craig S. 1984. Publishing the new poetry: Harriet Monroe's anthology. In: Journal of Modern Literature 11(1) (March), 89-108.

Aboussena, Mona 1986. Language as culture. In: Szabolcsi, Miklós; Kovács, József (eds.), Change in Language and Literature: Proceedings of the $16^{\text {th }}$ Triennial Congress of the Fédération Internationale des Langues et Littératures Modernes. Budapest: Akadémiai Kiadó, 201-230.

Abū Shādī, Aḥmad Zākī 1926. Al-shafaq al-bākī. Misr: al-Matba'ah al-Salfiyah.

Adūnīs 1958. Waḥdat al-ya's. In: Shi'r 7/8, 10-23.

Badawi, Muḥammad Muștafā 1973. Convention and revolt in modern Arabic poetry. In: von Grunebaum, Gustave Edmund (ed.), Arabic Poetry: Theory and Development. Wiesbaden: Otto Harrassowitz, 181-208.

Badawi, Muhamamad Muṣțafā 1975. A Critical Introduction to Modern Arabic Poetry. Cambridge University Press.

Beyers, Chris 2001. A History of Free Verse. Fayetteville, Arkansas: University of Arkansas Press.

37 The author wishes to thank the editors of Studia Metrica et Poetica for their guidance; the two anonymous readers for their comments and suggestions; and the participants in the conference "Words, Concepts, Metaphors: New Advances in Historical Semantics" at the University of Chicago in May 2014: Robert Bird, Joel Calahan, Monica Felix, Luba Golburt, Yury Kagarlitskiy, Ilya Kliger, Michèle Lowrie, Boris Maslov, William Nickell, Jillian Porter, Haun Saussy, Victoria Somoff, Davide Stimilli, and Leon Wash.

Nicholas Albertson, Mika Endō, and Mamiko Suzuki made incisive comments on a postconference draft of the paper.

This article is dedicated to my first Arabic teacher, Kay Heikkinen, and to the memory of my last Arabic teacher, Farouk Mustafa. 
Burnshaw, Stanley et al. (eds.) 2003. The Modern Hebrew Poem Itself: From the beginnings to 1990... One Hundred Five Poems in a New Presentation, a New and Updated Edition. Detroit: Wayne State University Press.

Cachia, Pierre 1990. An Overview of Modern Arabic Literature. Edinburgh: Edinburgh University Press.

Coffman, Stanley K. 1951. Imagism: A Chapter for the History of Modern Poetry. Norman, OK: University of Oklahoma Press.

Dāwūd, Anas 1967. Al-tajdìd fì shi'r al-mahjar. Cairo: Dār al-Kātib al-'Arabī.

Eliot, Thomas Stearns 1975. Selected Prose of T. S. Eliot. New York City: HBJ/Farrar, Straus and Giroux.

Elshakry, Marwa 2013. Reading Darwin in Arabic 1860-1950. Chicago: University of Chicago Press.

Finch, Annie 2000. The Ghost of Meter: Culture and Prosody in American Free Verse. Ann Arbor: University of Michigan Press.

Gasparov, Mikhail Leonovich 1996. History of European Versification. Oxford: Oxford University Press.

Genette, Gérard 1987. Seuils. Paris: Seuil.

Hattori Yoshika 1963. Kōgoshi shōshi. Tokyo: Shōrinsha.

Hitomi Enkichi 1954a. Kōgoshi no hattatsu (3). In: Gakuen (October), 6-106.

Hitomi Enkichi 1954b. Kōgoshi no hattatsu (4). In: Gakuen (November), 6-65.

Hitomi Enkichi (ed.) 1967. Nihon kindai shiron no kenkyū: sono shiryō to kaisetsu. Tokyo: Kadokawa shoten.

Hudson, Derek 1949. Martin Tupper: His Rise and Fall. London: Constable.

Imangulieva, Aida 2009. Gibran, Rihani and Naimy: East-West Interactions in Early Twentieth-Century Arab Literature. Thomson, Robin (trans.). Oxford: Inner Farne Press.

'Izz al-Dīn, Yūsuf 2007. Al-tajdìd fì al-shi'r al-hadìth. Damascus: Al-Mada.

Jacobowitz, Seth 2006. The Scene of Writing in Meiji Japan: Media, Language, and Realism in the Modern Japanese Novel. [Unpublished dissertation. Cornell University].

Jayyusi, Salma Khadra 1977. Trends and Movements in Modern Arabic Poetry (2 vols.). Leiden: Brill. 
Kamiyama, Tamie et al. (eds.) 1975. Toward a modern Japanese poetry. In: Literature East and West XIX, 1-4.

Kanbara Ariake 1967 [1908]. Genbun itchi no shiika. In: Hitomi Enkichi (ed.), Nihon kindai shiron no kenkyū: sono shiryō to kaisetsu. Tokyo: Kadokawa shoten, 333-334.

Karimi-Hakkak, Ahmad 1978. An Anthology of Modern Persian Poetry. Boulder, CO: Westview Press.

Karimi-Hakkak, Ahmad 1995. Recasting Persian Poetry: Scenarios of Poetic Modernity in Iran. Salt Lake City: University of Utah Press.

Khouri, Mounah 1987. The prose poem as a new form in modern Arabic poetry. In: Khouri, Mounah, Studies in Contemporary Arabic Poetry and Criticism. Piedmont, CA: Jahan Book Co., 101-121.

Kripke, Saul 1980. Naming and Necessity. Cambridge, Massachusetts: Harvard University Press.

Layoun, Mary 1990. Travels of a Genre: The Modern Novel and Ideology. Princeton University Press.

Lowell, Amy 1918. Can Grande’s Castle. New York: Macmillan.

Lowell, Amy 1921 [1914]. Sword Blades and Poppy Seed. Boston and New York: Houghton Mifflin.

Manfalūṭī, Mușṭafā Luṭ̂î 1965 [1912]. Mukhtārāt. Misr: al-Maktabah al-Tijārīyah alKubrā.

Manfredi, Paul 2014. Modern Poetry in China: A Visual-Verbal Dynamic. Amherst, NY: Cambria Press.

Mehl, Scott 2013. The Concept of Expression in Modern Japanese Poetics: Thought, Consciousness, Language. [Unpublished Ph.D. dissertation, University of Chicago].

Mehl, Scott 2015. The beginnings of Japanese free-verse poetry and the dynamics of cultural change. In: Japan Review 28, 53-82 (forthcoming).

Miki Rofū 1967 [1908]. Jiyū naru shiika. In: Hitomi Enkichi (ed.), Nihon kindai shiron no kenkyū: sono shiryō to kaisetsu. Tokyo: Kadokawa shoten, 354-357.

Moreh, Shmuel 1966. Blank verse (al-shi'r al-mursal) in modern Arabic literature. In: Bulletin of the School of Oriental and African Studies, University of London, 483-505.

Moreh, Shmuel 1968. Poetry in prose (al-Shi'r al-Manthūr) in modern Arabic literature. In: Middle Eastern Studies, 4(4), 330-360. 
Moreh, Shmuel 1974. Five writers of shi'r manthūr. In: Middle Eastern Studies 10(3), 229-233.

Moreh, Shmuel 1975. An outline of the development of modern Arabic literature. In: Oriente Moderno, Anno LV, 102, 8-28.

Moreh, Shmuel 1976. Modern Arabic Poetry 1800-1970: The Development of its Forms and Themes under the Influence of Western Literature. Leiden: Brill.

Moreh, Shmuel 1988 [1977]. Technique and form in modern Arabic poetry up to World War II. In: Moreh, Shmuel, Studies in Modern Arabic Prose and Poetry. Leiden: Brill, 116-135.

Moussa-Mahmoud, Fatma 1996. Changing technique in modern Arabic poetry: a reflection of changing values? In: Smart, Jack R. (ed.), Tradition and Modernity in Arabic Language and Literature. Surrey: Curzon, 61-74.

Naimy, Nadeem 1985. The Lebanese Prophets of New York. American University of Beirut.

Okkotsu Akio 1967. Kōgo jiyūshiron sono ta. In: Hitomi Enkichi (ed.), Nihon kindai shiron no kenkyū: sono shiryō to kaisetsu. Tokyo: Kadokawa shoten, 727-772.

Okkotsu Akio 1991. Jiyūshi sōseiki ni kansuru shōken. In: Gendai shijin gunzō Minshüshiha to sono shüken. Tokyo: Kasama shoin, 3-32.

Opacki, Ireneusz 2000. Royal genres. In: Duff, David (ed.), Modern Genre Theory. Pearson Education Limited, 118-126.

Oritake Ryōhō 1967 [1908]. Genbun itchi shi. In: Hitomi Enkichi (ed.), Nihon kindai shiron no kenkyū: sono shiryō to kaisetsu. Tokyo: Kadokawa shoten, 350-352.

Radwan, Noha 2012. Egyptian Colloquial Poetry in the Modern Arabic Canon: New Readings of Shi'r al-Ammiyya. New York: Palgrave Macmillan.

al-Rīhānī, Amīn 1910. Al-Rīḥānīyāt. Beirut: Maṭba'at al-'ilmīyāt.

al-Rīhānī, Amīn 1955. Hutāf al-awdiyāt: shi̛r manthūr. Beirut: Dār Rīhānī.

al-Rīhānī, Amīn 1957. Adab wa-fann. Beirut: Dār Rīhānī.

Scott, Clive 1980. French Verse-Art: A Study. Cambridge: Cambridge University Press.

Scott, Clive 1986. A Question of Syllables: Essays in Nineteenth-Century French Verse. Cambridge: Cambridge University Press.

Scott, Clive 1990. Vers Libre: The Emergence of Free Verse in France 1886-1914. Oxford: Clarendon Press. 
Scott, Clive 1998. The Poetics of French Verse: Studies in Reading. Oxford: Clarendon Press.

Shimamura Hōgetsu 1967 [1907]. Gendai no shi. In: Hitomi Enkichi (ed.), Nihon kindai shiron no kenkyū: sono shiryō to kaisetsu. Tokyo: Kadokawa shoten, 331-333.

Smart, Jack R. (ed.) 1996. Tradition and Modernity in Arabic Language and Literature. Surrey: Curzon Press.

Sōma Gyofū 1908. Mizukara azakeru shikai. In: Hitomi Enkichi (ed.), Nihon kindai shiron no kenkyū: sono shiryō to kaisetsu. Tokyo: Kadokawa shoten, 335-337.

Steele, Timothy 1990. Missing Measures: Modern Poetry and the Revolt Against Meter. University of Arkansas Press.

al-Tami, Ahmed 1993. Arabic 'free verse': the problem of terminology. In: Journal of Arabic Literature 24(2) (July), 185-198.

Taupin, René 1985. The Influence of French Symbolism on Modern American Poetry. New York: AMS Press.

Thomas, Julia Adeney 2001. Reconfiguring Modernity: Concepts of Nature in Japanese Political Ideology. Berkeley and Los Angeles: University of California Press.

Thompson, Vance 1900. French Portraits: Being Appreciations of the Writers of Young France. Boston: Richard G. Badger \& Co.

Tilley, Arthur 1886. La Fontaine’s Fables. In: Macmillan's Magazine 54 (1886), 250-260.

Tomasi, Massimiliano 2004. Rhetoric in Modern Japan: Western Influences on the Development of Narrative and Oratorical Style. Honolulu: University of Hawaii Press.

Twine, Nanette 1991. Language and the Modern State: The Reform of Written Japanese. London and New York: Routledge.

Ueda Bin 1901. Miotsukushi. Tokyo: Chikeidō shoten.

Ueda Bin 1967 [1905]. Kaichōon jo. In: Hitomi Enkichi (ed.), Nihon kindai shiron no kenkyū: sono shiryō to kaisetsu. Tokyo: Kadokawa shoten, 240-242.

van Gelder, Geert Jan 1996. Najīb al-Haddād's essay on the comparison of Arabic and European poetry. In: Smart, Jack R. (ed.), Tradition and Modernity in Arabic Language and Literature. Surrey: Curzon Press, 144-152.

Warren, Frederick Morris 1890. Review of Becker, Zur Geschichte der Vers Libres in der neu-französischen Poesie. In: Modern Language Notes 5(2) (February), 58. 
Whitman, Walt 1902 [1882]. Ventures on an Old Theme. In: Bucke, Richard Maurice; Harned, Thomas B.; Traubel, Horace L. (eds.), The Complete Writings of Walt Whitman, vol. 5. New York and London: G. P. Putnam's Sons, 270-274.

al-Yāfì, Na'īm 1986. Al-shi'r al-'arabì al-hadìth. Damascus: Dār al-Majidd.

Yeh, Michelle 1991. Modern Chinese Poetry: Theory and Practice since 1917. New Haven and London: Yale University Press. 